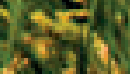

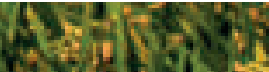

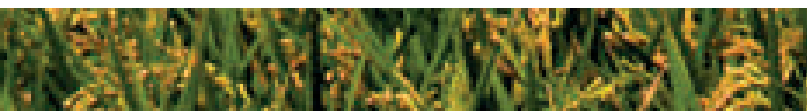

Sia

Pexpry

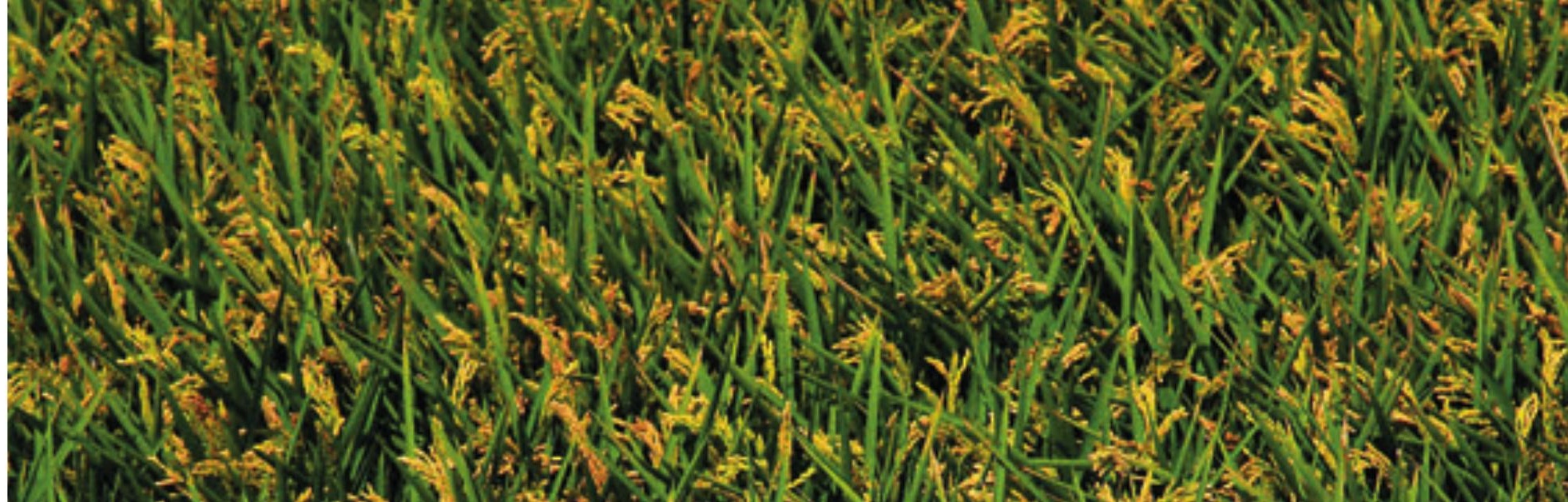

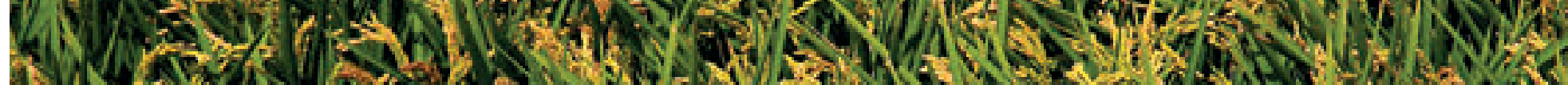

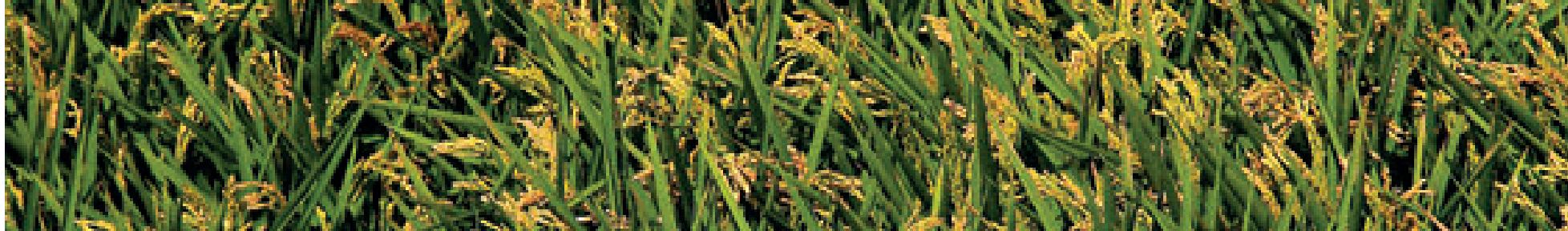

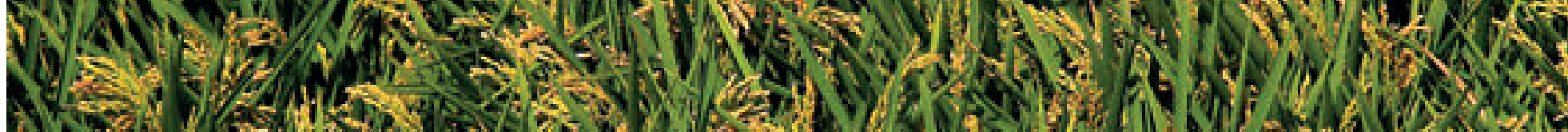

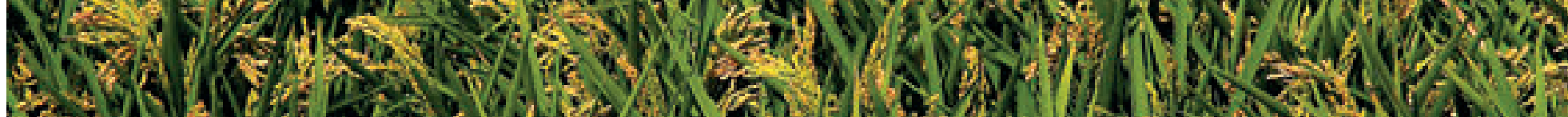
Q6. S.

Nos:

(3)

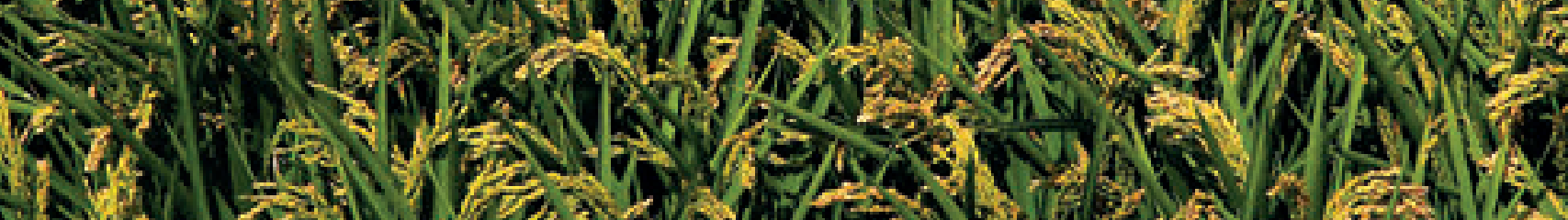

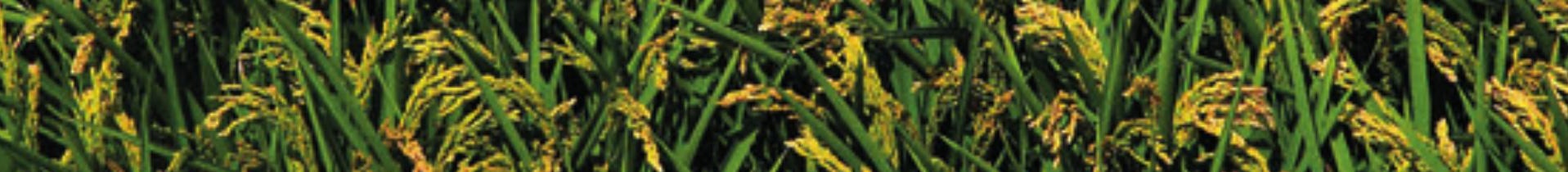

Q

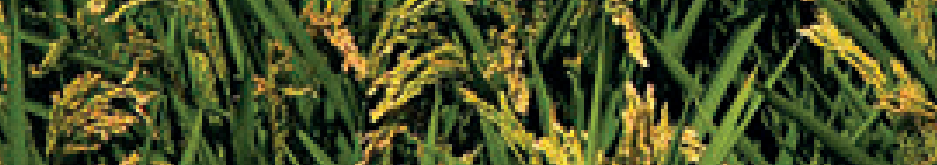

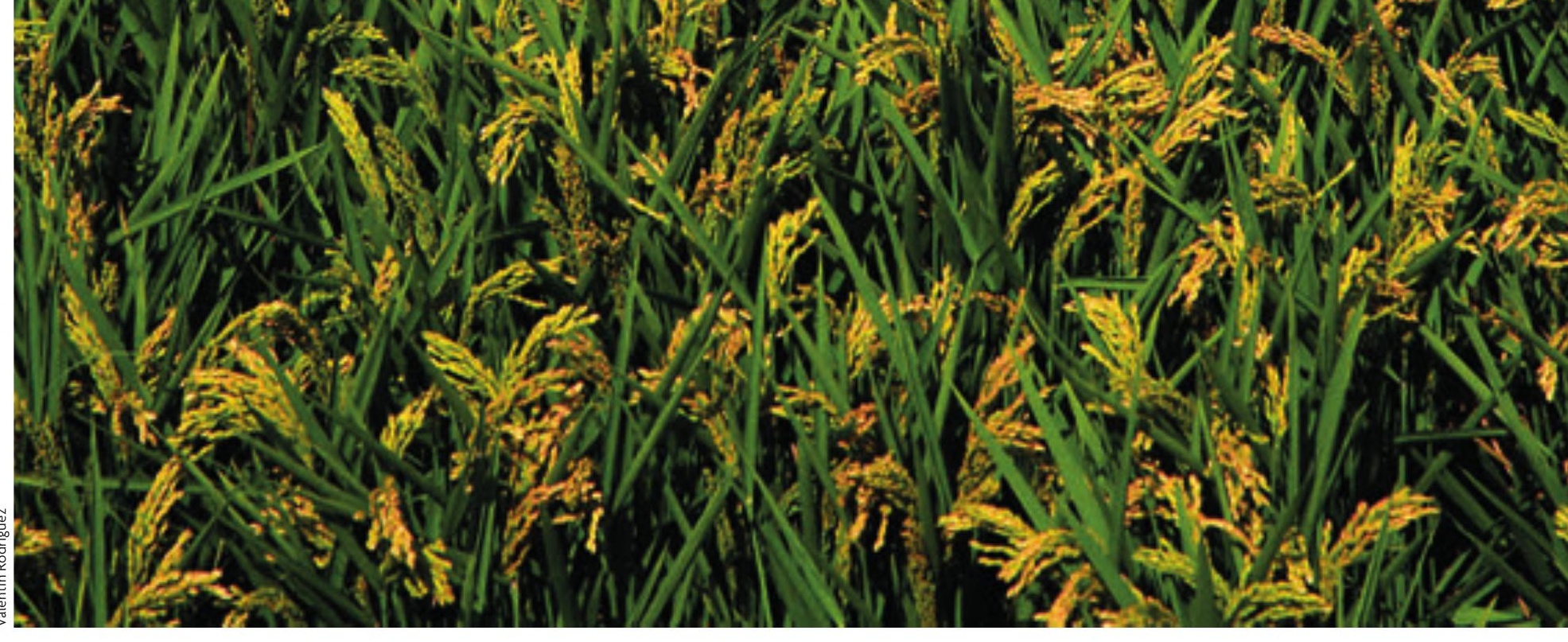

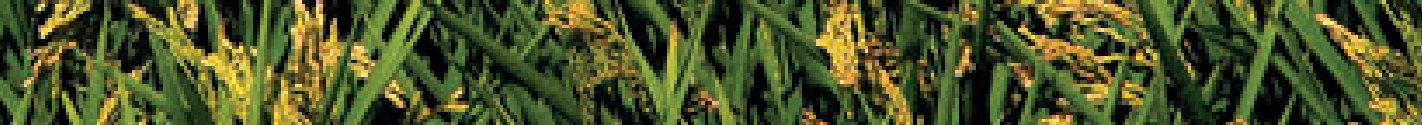

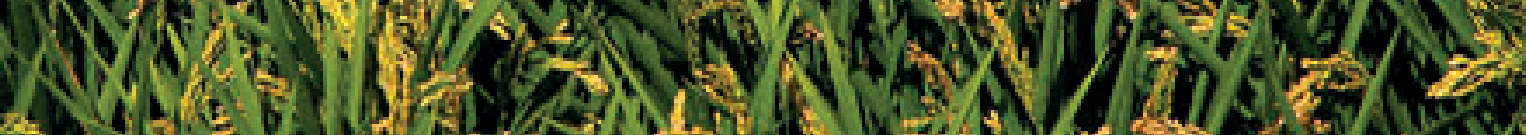




\title{
GENETICALLY MODIFIED CROPS 2.0 THE DECLINE OF MEDIA CONTROVERSY IN DIGITAL JOURNALISM
}

\author{
MARIA JOSEP Picó
}

\begin{abstract}
The controversy over the effects of GM crops on nature and health was one of the most intense media debates of the late twentieth century. Despite the existence of Web 2.0 tools for the transmission of information, the controversy is now declining in digital media, with the exception of France and the United Kingdom, where the debate is still ongoing among citizens and environmental action is constant.
\end{abstract}

Keywords: digital journalism, environment, GM crops, biotechnology, blogs.

GM crops and the controversy about their possible effects on biodiversity and health constituted an essential topic for environmental journalism in Europe in the 1990s, when other alarms, such as human cases of bovine spongiform encephalopathy (also known as mad cow disease) or avian flu, also threatened food safety (Gaskell, Bauer, Allum, \& Durant, 1999). In 1996, thirteen years after laboratories produced the first genetically modified plant, the first genetically modified crop approved in the USA, the Flavr Savr tomato, was withdrawn from the market due to a lack of commercial success. Meanwhile, in the European Union, the social and political controversy over biotech crops worsened. The conflict led to the decision, in 1998, to establish a moratorium for new authorisations. This lasted for five years and caused the USA to protest to the World Trade Organization.

Unlike other branches of biotechnology that are more closely associated with technological progress or healthcare advancement (drugs, vaccines, etc.) in the minds of the public and enjoy a wider social acceptance and consensus, information on genetically modified crops has faced flashy rejection campaigns in Europe, promoted by environmental organisations, sometimes in partnership with consumers and small producers. These actions, having a prominent visual component, are highly effective in catching the attention of the media, to the detriment of qualified scientific voices. These conservationist interventions have, therefore, contributed to the politicisation of science (Ansell, Maxwell, \& Sicurelli, 2006). Uncertainty and new risks of biotechnological crops have made it more difficult for journalism and social communication to tackle the topic (Howarth, 2006), which is integrated into the set of environmental issues that give rise to societal fears, because their long-term impacts are unknown - problems like nuclear plant accidents, global warming or chemical pollution (Cox, 2006). So much so that scientists insist on the need for more impartial information and less propaganda (Arntzen, Coghlan,

Johnson, Peacock, \& Rodemeyer, 2003) because the debate on GM crops is a mixture of broader concerns, among which are intellectual property rights and corporate dominance over seeds (Qaim, \& Zilberman, 2003).

The polarisation of communication in this branch of biotechnology had an effect on the economy and science, halting public research and industrial projects even though the positive impact of GM crops had been proved by farmers, especially in developing countries, where they yielded better harvests, higher profit or reduced demand for pesticides 
(Carpenter, 2010). And let us not forget the truth about the consequences of farming with GM seeds with resistance to herbicides, such as the proliferation of large quantities of weeds (Gilbert, 2013). Nevertheless, although these crops can help to grow plants that are more resistant to adverse weather conditions or to create foods with nutritional supplements, the combination of genes from different species is perceived as a rather unnatural practice (Shaw, 2002), so the scientific education of society can influence the acceptance of new food applications of genetic technology (Mielby, Sandøe, \& Lassen, 2013).

European citizens have been more resistant to GM crops than citizens of the USA, where biotech crops and food have greater social support. However, paradoxically, press coverage in the old continent tends to be more positive (Gaskell et al., 1999). Growing concern about this topic led the British government to start a public debate in 2002 to determine whether genetically modified organisms should be grown commercially within their territory (Barbagallo \& Nelson, 2005). Currently, Europeans still cannot see the benefits of GM foods; they are considered unsafe and even harmful. Consequently, they stand against their development (Eurobarometer, 2010).

\section{SILENCE IN THE SPANISH PRESS}

Following the declaration of 2014 as the International Year of Biotechnology by the Spanish Federation of Biotechnologists, we set out to follow the incidence of news on GM crops in the most important Spanish digital newspapers during the first half of 2014. We focus on Web 2.0 journalism; the Internet is already the first source of information for scientific topics, so scientists must pay attention to these new trends (Brossard \& Scheufele, 2013), and also because the proliferation of blogs changes the relationship between journalists and scientists as researchers create competing channels for the communication of scientific news (Colson, 2011).

The study of digital publications, as well as journalistic science and environmental blogs linked to Spanish prestige newspapers, reveals a scarcity of biotechnology news. El País is the only national newspaper with a specific section called «Agricultura transgénica» - we will later see that The Guardian also has one. However, only two news items were published during the analysed period, one in «International» and the other one in «Society», and neither were written by a specialised environmental journalist. Each had differing

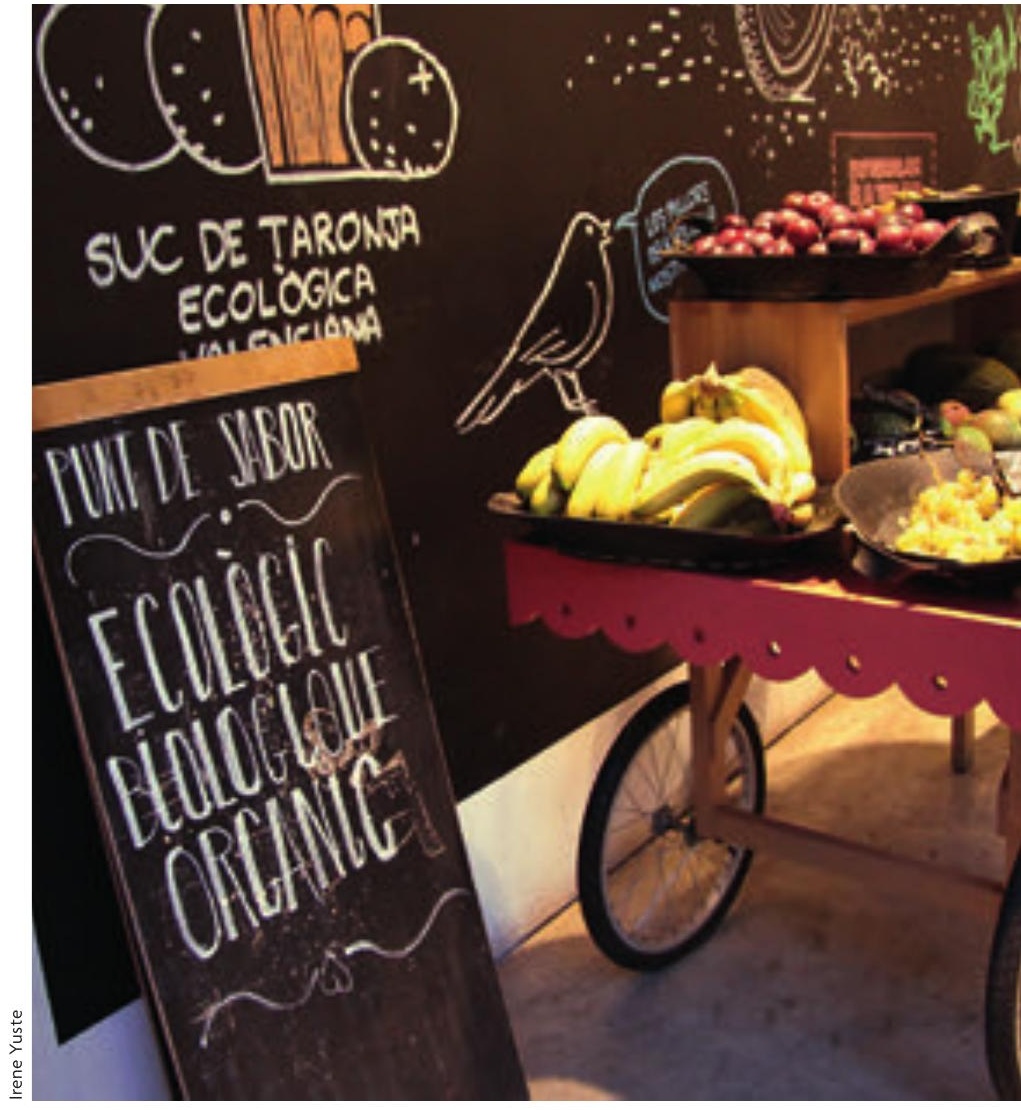

Although these crops can produce plants that resist adverse climate conditions better or create food with nutritional supplements, the combination of genes from different species is perceived as a rather unnatural practice.

success in social networks. The first piece, titled «La mala imagen fuerza a Monsanto a cambiar de estrategia» ("Monsanto's negative image forces a strategic change"), was recommended 2,860 times on Facebook; the second, on the possibility that European countries would ban GM crops, was only shared five times on Facebook and more than 400 times on Twitter. On the other hand, we have to go back to 2011 to find a side reference to GM crops in the most important environmental blog in El País, Ecolaboratorio, by the environmental journalist Clemente Álvarez. The article is «Los 1.216 litros de agua de una pizza margarita» ("The 1,216 litres of water in a margherita pizza").

El Mundo does not show excessive interest in dealing with GM crops, either. During the first six months of the year, they published three articles in three different sections: «Science», «Politics» and «Economy». In addition, two other articles that dealt with disruptive technologies and conflicts between innovation and ethics referred to the topic. They were 

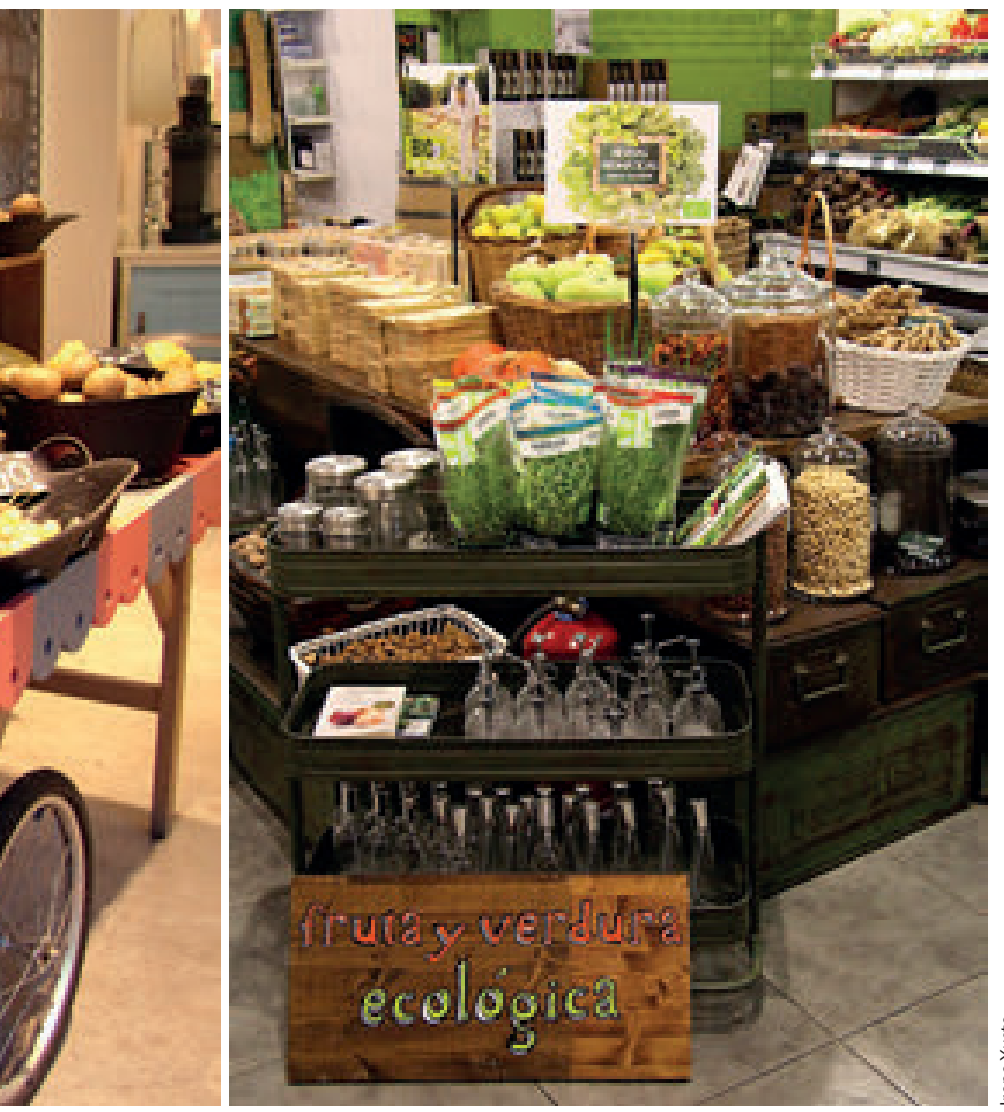

Lastly, $A b c$, also displaying the lack of media attention on GM crops, repeats the dynamic detected in El Mundo, that is, including articles about GM food in special supplements. We found two articles there. The article by Verónica Goyzueta from São Paulo, «Polémica en Brasil por la liberación de mosquitos transgénicos contra el dengue» ("Controversy in Brazil over GM mosquitoes released to fight dengue fever"), was published in Abc Salud, while the second, related to a report on GM crops around the world by Friends of the Earth, was included in the Abc Natural supplement. The impact of these reports varies between 100 and 300 tweets, but is more variable on Facebook, with the first receiving moderate attention and the second, «El $90 \%$ de los transgénicos se cultivan solo en seis países» ("90\% of GMOs are grown in only six countries"), being shared more than 700 times, perhaps because the source is an environmentalist collective that is quite active on social networks.

\section{THE EUROPEAN DIGITAL LANDSCAPE}

Given the low coverage of GM crops in the Spanish press, we decided to check its incidence in the prestigious European press. The Guardian, in the «OGM» subsection of «Environment», presents thirteen news items on GM food during May and June included in the «Innovation» subsection in «Economy», which shows the tendency to isolate this environmental issue instead of dealing with it broadly in the daily news. The most shared Facebook item, with more than 500 clicks (although it was not shared on Twitter), is «¿Quién teme al tomate morado?»
«THE POLARISATION OF COMMUNICATION IN THIS BRANCH OF BIOTECHNOLOGY HAD AN EFFECT ON THE ECONOMY AND SCIENCE, STOPPING PUBLIC RESEARCH AND INDUSTRIAL PROJECTS» 2014 - published in several sections, particularly related to business -, with more sources, authors and more powerful Web 2.0 projection both in social networks and reader feedback through the articles' comments section. The subject that generates the most attention during this period is: «Vermont becomes first US state to require tomato?"), by Carlos Fresneda, London correspondent and expert on ecology. It was published in the «Science» section. Secondly, «Los "productos" de la "Revolución Verde" de Monsanto» ("The 'products' of Monsanto's 'Green Revolution"'), by Pablo Pardo, from Washington, was included in «Economy» and was shared a hundred times on Facebook but had little incidence on Twitter. Regarding the environmental blogs of this newspaper, Tierra, by the naturalist Joaquín Araújo, does not mention the topic, unlike Ecohéroes, by the specialised journalist Carlos Fresneda. Despite this, no related articles were found for the studied period and we had to go back to 2013 to find references to GM crops.
GM labelling for food», by Suzanne Goldenberg in «Environment». It was recommended 4,793 times on Facebook, an inconceivable figure for national digital media, retweeted 200 times and commented on 116 times. The most commented article, though, was published in «Environment» and boasted 135 contributions: «GM contamination rules should be relaxed, says biotechnology scientist», by Brendan Foster. The impact on social networks of «GMO 2.0: Genetically modified foods with added health benefits» is also worth noting. It was written by Marc Gunther and included in Guardian Sustainable Business. 
GM crops do not receive the same coverage, however, in the environmental blogs of the British newspaper. The head of the «Environment» section, Damian Carrington, and the environmentalist George Monbiot, did not touch the topic during the first semester, and during May and June, in the Environment Blog, we only find Johnny Langenheim's text «Why we should be worried about "Frankenfish" in South-east Asia», with a discreet impact on social networks.

In France, anti-GMO activism is the strongest in Europe, not least because the country is the primary agricultural power in the continent - despite agriculture being no more than $2 \%$ of its GDP. Therefore, newspapers like Le Monde amply display this social interest in GM crops. The subsection «Agriculture \& Alimentation» in «Planète» published nine pieces between May and June, six of them during the latter month. The French newspaper, on the other hand, is less committed to social networks and audience interaction than The Guardian, and prioritises its subscribers. The article titled «Monsanto investit 137 millions d'euros dans deux usines en France» ("Monsanto invests 137 million euros in two French factories") was the one with most Facebook shares in that period $(1,690)$, followed in social media reach by «Toxicité du Roundup et d'un OGM: Séralini republie son étude controversée» ("The toxicity of Roundup and a GMO: Séralini publishes controversial study again"). Furthermore, the article «La France pourra interdire la culture d'OGM sur son sol» ("France will be able to ban GMOs in its territory") by the newspaper's environmental journalist, Audrey Garric, and the Brussels correspondent Philippe Ricard has more than twenty comments, far from the more than one hundred in The Guardian. Le Monde's concerns regarding GM crops are also displayed when their digital edition opened the public debate in June on the European Union's decision to let each country veto GMO farming with the question: «Voulez-vous des OGM en Europe?» ("Do you want GMOs in Europe?"). Regarding Le Monde's environmental blogs, none normally analyse GMOs, not even the environmental journalist Audrey Garric in Eco(lo).

In Italy, digital publications with recognised environmental sections, such as La Repubblica, do not usually follow agricultural applications of

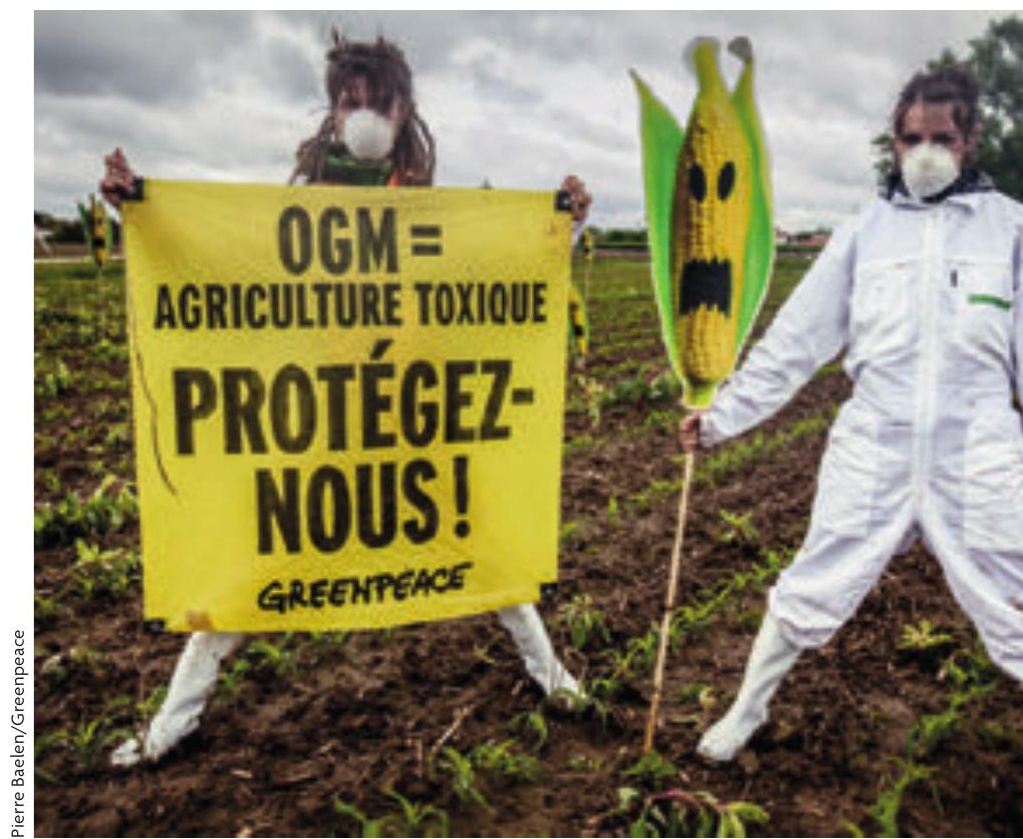

In Europe, information on GM crops has been captured by rejection campaigns promoted by environmentalist organisations. In the pictures, a Greenpeace anti-GMO campaign in France in 2014. biotechnology. The news article «Ogm, accordo Ue: "gli Stati decideranno se coltivarli"» ("Agreement in the EU: each state will decide whether or not they farm GMOs"), with 400 Facebook recommendations, is worth noting, as is a blog entry from the same day in Guglielmo Pepe's blog: «Ogm in agricoltura, una scelta da Tafazzi» ("GMOs in agriculture, a choice by Tafazzi"), with little social network resonance. As in Le Monde, despite the existence of several environmental blogs, such as Eco-logica, by the environmental journalist Antonio Cianciullo, they do not address GM crops.

The decline of media controversy over GMOs in the digital media, particularly in Spain and Italy, leads us to consider what is happening in the general blogosphere, as the digital environment is causing the emergence of new science communication alternatives (Allan, 2009). We observe that there is a similar trend, as GM scepticism is not fuelled by science. In the Spanish language blogring Naukas, the two authors who have delved more into this matter are José Manuel López Nicolás with Scientia - although not during the analysed period - and José 

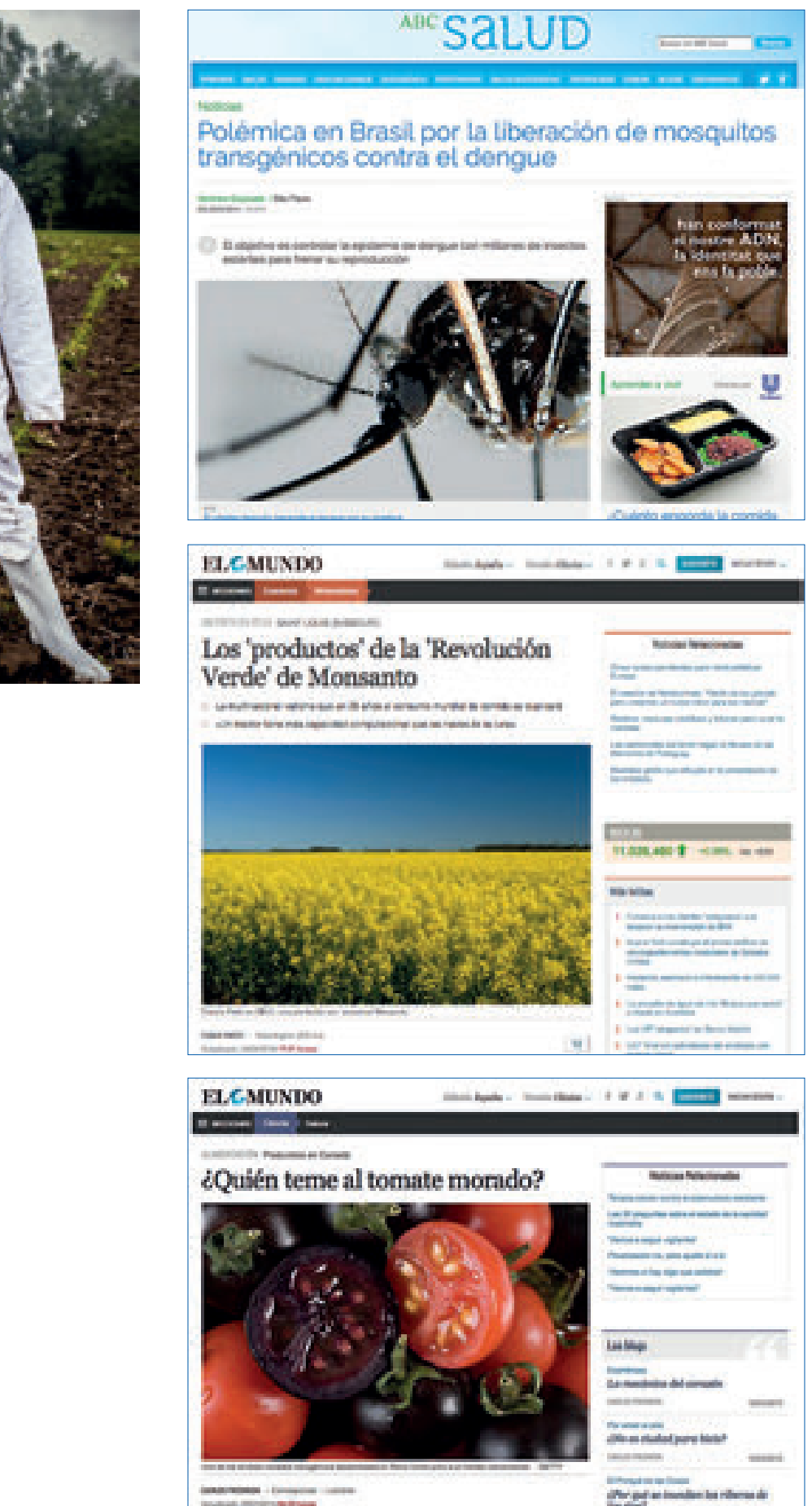

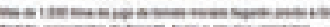
con

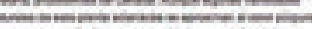
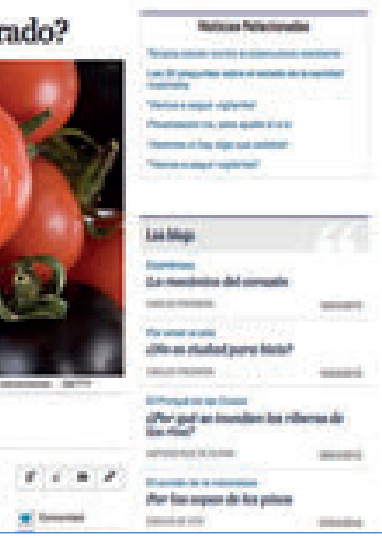

During the first half of 2014, International Biotechnology Year, GMO coverage in the Spanish press was scarce. In the pictures, some of the information pieces on this matter published by $A b c$ and El Mundo during the analysed period.
Miguel Mulet, who touches on different topics related to GMOs in his blog Tomates con genes, such as their applications in the prevention of diseases like dengue fever. He also criticises Greenpeace's anti-GMO actions and even led the debate against the claims of anti-GMO scientist Elena Álvares Buylla published in Eldiario.es.

In the English-speaking sphere, there is the Scienceblogs.com aggregator, where we find the blog GMO by the scientist Pamela Ronald and Respectful insolence, whose author writes under the pseudonym Orac but describes him or herself as a scientist. However, to find comments on GMOs one must go back to 2012 and 2013, respectively. As for the French scientific blog community, C@fé des Sciences, the controversy regarding GMOs is not found, although France is the European country where the debate is most active and intense. Thus, the last time the scientist Marc Robinson-Rechavi wrote about the issue on the blog Tout se passe comme si was in July 2013.

\section{«THE DECLINE OF MEDIA CONTROVERSY ON GMOs IN DIGITAL MEDIA, PARTICULARLY IN SPAIN AND ITALY, LEADS US TO CONSIDER WHAT IS HAPPENING IN THE GENERAL BLOGOSPHERE»}

\section{SUCCESS IN SOCIAL NETWORKS}

Finally, after observing the digital press and the blogosphere, we ask ourselves whether the most belligerent environmentalist groups regarding antiGMO campaigns, Greenpeace and Friends of the Earth, are still worried about this environmental and biotechnological challenge. The Spanish blog by Friends of the Earth shows a low level of activism at the national level. In May, they published: «Firma y envía tu mazorcazo para prohibir los cultivos transgénicos» ("Sign and send your corncob to ban GM crops") and «STOP a los transgénicos» ("Stop GMOs"), and in April, «Petición denegación del experimento con moscas transgénicas» ("Petition for the rejection of the experiment with GM flies"). Surprisingly, Greenpeace Spain did not touch the topic of GMOs in their blog during the first half of 2014, with the exception of a note in February: «iInterpretación sesgada o baile de cifras transgénicas?» ("Biased interpretation or GM numbers 
dance?"). In fact, in the USA, the country with the highest production and consumption of GMOs, this organisation organises barely any campaigns.

The communication strategy of the international environmentalist organisation is different depending on the country: in the United Kingdom and Italy activity is very low. In the latter they responded to the European decision to let each country decide with the criticism «Vietare gli OGM a livello nazionale: accordo o trappola?» (“The GMO national ban: agreement or trap?"). However, Greenpeace news in France shows not only opinion, but continuous protest actions against these crops. It also has enormous success on Facebook - Twitter response is low - and interaction with supporters and members, with more than a thousand comments, for instance, in the entry «Maïs OGM: la saga continue!» ("GM corn: the saga continues!"), and the 14,000 Facebook recommendations of «Les OGM contaminent aussi la France!» (“GMOs pollute France as well!"’). The piece «Action: du maïs OGM MON810 planté en France!» (“Action: GMO MON810 farmed in France!") also had over 5,000 shares and 200 comments.

The controversy over GM crops that appeared during the nineties has declined substantially and is almost dead in the Spanish digital media, despite the improvements in communication of the Web 2.0 communicative environment. Nonetheless, the situation in Europe is not homogeneous: citizen participation and interaction in the digital environment keep the debate on GMOs alive in France and the United Kingdom. This is clear when we look at the recommendations of The Guardian's or Le Monde's articles - hundreds or even a thousand in social networks and at the comments submitted by their readers.

Conversely, the blogosphere, both the general and the journalistic one, does not reflect the GM controversy in any country in the old continent, probably because the voice of science has not made lobbying efforts in this debate. On the other hand, the Web 2.0 online world has become a fundamental tool for the international environmentalist organisation Greenpeace in a country, France, which is considered the primary agricultural power in the European Union. They use the technology in order to keep fighting against GMOs, both in protest actions and with information coverage on the web and social networks, where the conservation organisation is very successful in disseminating their slogans. Some of their contents exceed the target of 14,000 recommendations. The common features of European digital media in relation to GMOs are the conquest of the economy sections, leaving science and environment sections behind, while they transfer their attentions in favour of new environmental issues, as popular and troublesome as climate change, fracking and other issues related, especially, to energy production.

\section{REFERENCES}

Allan, S. (2009). The future of science journalism. Journalism, 10, 280. doi $10.1177 / 1464884909102570$

Ansell, C., Maxwell, R., \& Sicurelli, D. (2006). Protesting food: NGOs and political mobilization in Europe. In C. Ansell, \& D. Vogel (Eds.), What's the beef? The contested governance of European food service. Massachusetts: MIT Press.

Arntzen, C. H., Coghlan, A., Johnson, B., Peacock, J., \& Rodemeyer, M. (2003). GM crops: Science, politics and communication. Nature Reviews Genetics, 4, 839-843. doi: $10.1038 / \mathrm{nrg} 1185$

Barbagallo, F., \& Nelson, J. (2005). UK GM dialogue: Separating social and scientific issues. Science Communication, 26, 318. doi: $10.1177 / 1075547004273091$

Brossard, D., \& Scheufele, D. A. (2013). New media, and the public. Science, 339, 40. doi: 10.1126/science.1232329

Carpenter, J. E. (2010). Peer-reviewed surveys indicate positive impact of commercialized GM crops. Nature Biotechnology, 28, 319-321. doi: 10.1038/nbt0410-319

Colson, V. (2011). Science blogs as competing channels for the dissemination of science news. Journalism, 12, 889. doi: $10.1177 / 1464884911412834$

Cox, R. (2006). Environmental communication and the public sphere. California: Sage Publications.

Eurobarometer. (2010). Biotechnology. Special eurobarometer 341. Wave 73.1. TNS Opinion \& Social. Brussels: European Commission.

Gaskell, G., Bauer, M., Allum, N. C., \& Durant, J. (1999). Worlds apart? The reception of genetically modified foods in Europe and the United States. Science, 285(5426), 384-386. doi: 10.1126/science.285.5426.384

Gilbert, N. (2013). Case studies: A hard look at GM crops. Nature, 497, 24-26. doi: $10.1038 / 497024$ a

Howarth, A. (2006). Participatory politics, environmental journalism and newspaper campaigns. Journalism Studies, 13(2), 210-225. doi: 10.1080/1461670X.2011.646398

Mielby, H., Sandøe, P., \& Lassen, J. (2013). The role of scientific knowledge in shaping public attitudes to GM technologies. Public Understanding of Science, 22(2), 155-168. doi: 10.1177/0963662511430577

Qaim, M., \& Zilberman, D. (2003). Yield effects of genetically modified crops in developing countries. Science, 299(5608), 900-902. doi: 10.1126/ science.1080609

Shaw, A., (2002). It just goes against the grain: Public understandings of genetically modified (GM) food in the UK. Public Understanding of Science, 11(3), 273-291. doi: 10.1088/0963-6625/11/3/305

Maria Josep Picó. Environmental journalist and Professor of the Master in Scientific, Medical and Environmental Communication of the Pompeu Fabra University (Barcelona, Spain). She is a science communicator and author of several essays. She won the National Environmental Journalism Award. 